\title{
The extreme flood in June 2013 in Germany
}

\author{
Bruno MERZ¹, Florian ELMER', Michael KUNZ², Bernhard MÜHR², Kai SCHRÖTER', \\ Steffi UHLEMANN-ELMER ${ }^{3}$
}

\author{
1. GFZ German Research Centre for Geosciences, 14473 Potsdam, Germany \\ bmerz@gfz-potsdam.de,elmer@gfz-potsdam.de,kai.schroeter@gfz-potsdam.de \\ 2. KIT Karlsruhe Institute of Technology,76131Karlsruhe,Germany,kunz@kit.edu,muehr@kit.edu \\ 3. Aspen Re, Catastrophe Risk Management, Research and Development,8001 Zurich, Switzerland, steffi.uhlemann@aspen-re.com
}

\begin{abstract}
The June 2013 flood was the most severe large-scale flood in Germany, at least for the last 6 decades for which a hydrological flood severity has been calculated. Many gauges along the Elbe and Danube rivers showed record water levels. The flood severity index, a measure which combines magnitude and spatial extension, is almost twice as large as the index of the August 2002 flood which has been the most expensive natural disaster for Germany to date. The enormous hydrological severity was caused by widespread and intense rainfall in combination with wet catchments due to exceptionally high rainfall in the month preceding the event. Preliminary damage estimates are in the order of 8.7 to 12 billion $€$. Hence, the losses seem to be lower compared to the 2002 flood (11.8 billion $€$ for Germany). Although detailed analyses have not been performed to date, it can be assumed that the investments and improvements in flood risk management since 2002 have reduced the flood risk and prevented higher damage.
\end{abstract}

Key-words: Floods, flood-of-record, damages, risk management

\section{La crue extrême de juin 2013 en Allemagne}

\begin{abstract}
RÉSUMÉ. - La crue de juin 2013 a eu une très large extension spatiale, avec de nouvelles valeurs record de crue sur les bassins de l'Elbe et du Danube. Elle se situe en première position depuis 60 ans sur une échelle de sévérité hydrologique, qui combine intensité et extension spatiale. La valeur de cet indice de sévérité est deux fois plus forte que celle de la crue d'août 2002, qui a été l'événement naturel le plus dommageable à ce jour. Le caractère exceptionnel de la crue est lié à l'occurrence de pluies intenses sur de nombreux bassins, qui étaient déjà largement saturés par les précipitations du mois précédent. Les premières estimations des dommages sont comprises entre 8.7 et 12 milliards d'euros et sont a priori inférieures au montant des dommages de la crue de 2002 (11.8 milliards d'euros en Allemagne). Dans l'état actuel des investigations, il semblerait que les actions réalisées depuis 2002 pour la prévention et la gestion du risque d'inondation ont permis de réduire les effets de la crue de 2013.
\end{abstract}

Mots-clés : Crue, record de crue, dommages, gestion du risque d'inondation

\section{INTRODUCTION}

In June 2013, several parts of Central Europe were hit by large-scale flooding. Particularly Southern and Eastern Germany were affected, but also other countries such as Austria, Switzerland, Czech Republic, Poland, Hungary, Slovakia, Croatia and Serbia. The flooding in Germany was caused by heavy rain persisting over several days in combination with wet catchments; a strong rainfall anomaly in May had led to very high soil moisture over large parts of Germany. Almost all rivers in Germany showed high water levels. Severe flooding occurred especially along the Danube and Elbe rivers, as well as along the Elbe tributaries Mulde and Saale. The current preliminary economic loss estimates for Germany are in the range of 8.7 to 12 billion $€$. The upper number is very similar to the loss that has been caused by the extreme summer flood in August 2002 - the most expensive natural hazard experienced so far in Germany.

This paper gives a short characterization of the meteorological and hydrological aspects of the June 2013 flood, summarizes the flood impact, and concludes with some impressions on the state of flood risk management in Germany.

\section{HYDRO-METEOROLOGY OF THE JUNE 2013 FLOOD}

\section{II.1. Precipitation and initial conditions}

In May and June 2013, Central Europe experienced several similar meteorological situations with a cut-off upper low pressure zone above Germany that moved slowly eastwards. On its eastern side, warm and moist air masses were continuously advected from the sub-tropics to northern and Central Europe. Several low pressure systems in succession induced long periods of widespread and intense rainfall, which was additionally enforced by orographic uplift over the low mountain ranges in Germany and the northern side of the Alps. A particular feature of the June 2013 flood was the combination of high rainfall and very wet initial catchment conditions. The month of May 2013 was the second wettest May since 1881 and showed $180 \%$ of the long term monthly mean precipitation [CEDIM, 2013a].

Figure 1 (left) shows for Germany the 30-day Antecedent Precipitation Index (API), which is the sum of daily precipitation (1-30 May) weighted with respect to the time span to the maximum in June. Large parts of central, east and south 

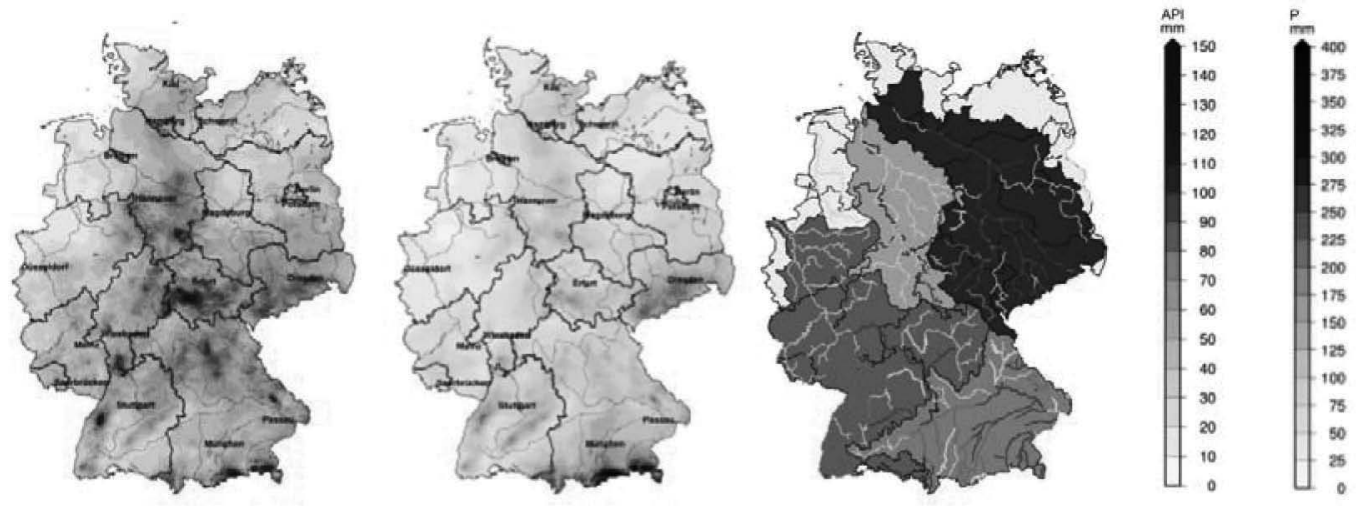

Major river network

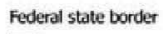

$\square$

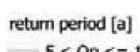

$5<Q p<=10$

$-10<Q p<=50$

$-50<Q D<=100$

$-Q p>100$

$\square$ Danube

Elbe

$\square$ Rhine

$\square$ Weser

Fig. 1: 30-day Antecedent Precipitation Index API (left), 7-day precipitation totals (middle) and statistical return periods of maximum peak discharges (right) for the June 2013 flood. (Data sources: REGNIE data sets of the German Weather Service (DWD) on a $1 \times 1 \mathrm{~km}^{2}$ grid, gauge data made available by Water and Shipping Management of the Fed. Rep. (WSV) prepared by Federal Institute for Hydrology (BfG) and environmental state offices of the federal states. Flood return periods are based on data collected up to 20 June 2013.)

Germany show unusually high values of API in May. These values are significantly higher compared to other record floods in Germany. Hence, soils were already very wet or even saturated when the flood-causing rainfall began at the end of May. Wet soils and catchments favored fast and high runoff generation.

The most intense rainfall occurred between 31 May and 4 June with a successive west-to-east shift. The maximum 7-day totals, quantified separately for each grid point as running means, confirm that the flood-triggering rainfall can be characterized by a large spatial extent, covering most parts of southern and eastern Germany, particularly the Danube and Elbe catchments (Fig. 1, middle). Highest values around $200 \mathrm{~mm}$ occurred over the Ore mountains (southeast of Dresden), the Black Forest mountains (west of Stuttgart), Swabian Jura (east of Stuttgart), and over the Alps in Bavaria (south of Munich). Several parts of eastern Germany were additionally hit by convection and thunderstorms. Extreme value statistics of maximum 7-day rainfall totals yield return periods below 50 years for most of the areas. However, several hot spots, especially over the aforementioned low mountain ranges and the Alps showed return periods in excess of 200 years (not shown here).

\section{II.2. Discharge peaks}

The June 2013 flood was a large-scale, trans-basin flood: All major river basins in Germany showed flooding, including the Weser, upper Rhine (Main, Neckar), Elbe and Danube catchments. Heavily affected were the Danube and Elbe rivers and some of their tributaries. For example, the city of Passau at the confluence of Danube and Inn showed a record water level of $12.75 \mathrm{~m}$. This is the highest water level since the historical flood of 1501 (discharge for this historical flood is unknown). Floods of record were observed at many gauges in the Danube and Elbe catchments (Figure 2). Especially along the Elbe, the maximum water levels observed since the installation of the gauges were exceeded on a river stretch of $250 \mathrm{~km}$ between Coswig and Lenzen [BfG, 2013]. Based on the data from nine gauges, which showed record water levels along the Elbe and Danube rivers, the mean observation period for discharge is 100 years (range: 78-121 years of observations). Systematic water level observations are expected to have started even earlier, hence, the values of the June 2013 flood may be record values for even longer periods.

Figure 1 (right) illustrates the hydrological extent of the June 2013 flood in terms of return periods. Several fractions of the river network in the Elbe and Danube catchments were affected by flood peaks larger than the 100 year flood. More than $60 \%$ of the German river network considered was affected by flood peak discharges exceeding a statistical return period of two years.

\section{FLOOD IMPACTS}

The extreme water levels and discharge values led to extensive inundations, including a number of flood defense failures. Large-scale inundations occurred as consequence of dike breaches near Deggendorf (Danube), Groß Rosenburg (Saale) and Fischbeck (Elbe). Additionally, a considerable number of smaller dike breaches leading to less extensive inundations areas was recorded, e.g., 5 breaches at the Elbe river in Saxony, and 19 dike breaches at the Mulde river [BfG, 2013].

First estimates of total economic damage amount to 8.7 to 12 billion $€$ for Germany alone [Die Bundesregierung, 2013, Fitch Ratings, 2013, GdV, 2013]. A special reconstruction aid fund of 8 billion $€$ has been implemented by the federal states and the German federal government (Aufbauhilfegesetz came into effect on 19 July 2013), to cope with the flood impacts. The insurance industry estimated 180.000 damage claims summing up to 2 billion $€$ insured damages [GDV, 2013].

More than 52.000 people had to be evacuated during the June 2013 floods. Further, it claimed 8 lives in Germany, and the total number of fatalities in all affected countries was 25. The German Farmers' Association estimated that 250.000 hectares of grasslands and crop fields were inundated. Large industrial companies, e.g., Porsche AG in Leipzig, Volkswagen AG in Zwickau or Südzucker AG in Zeitz, had to stop their production due to direct flood effects or indirect effects as consequence of supply chain disrup- 


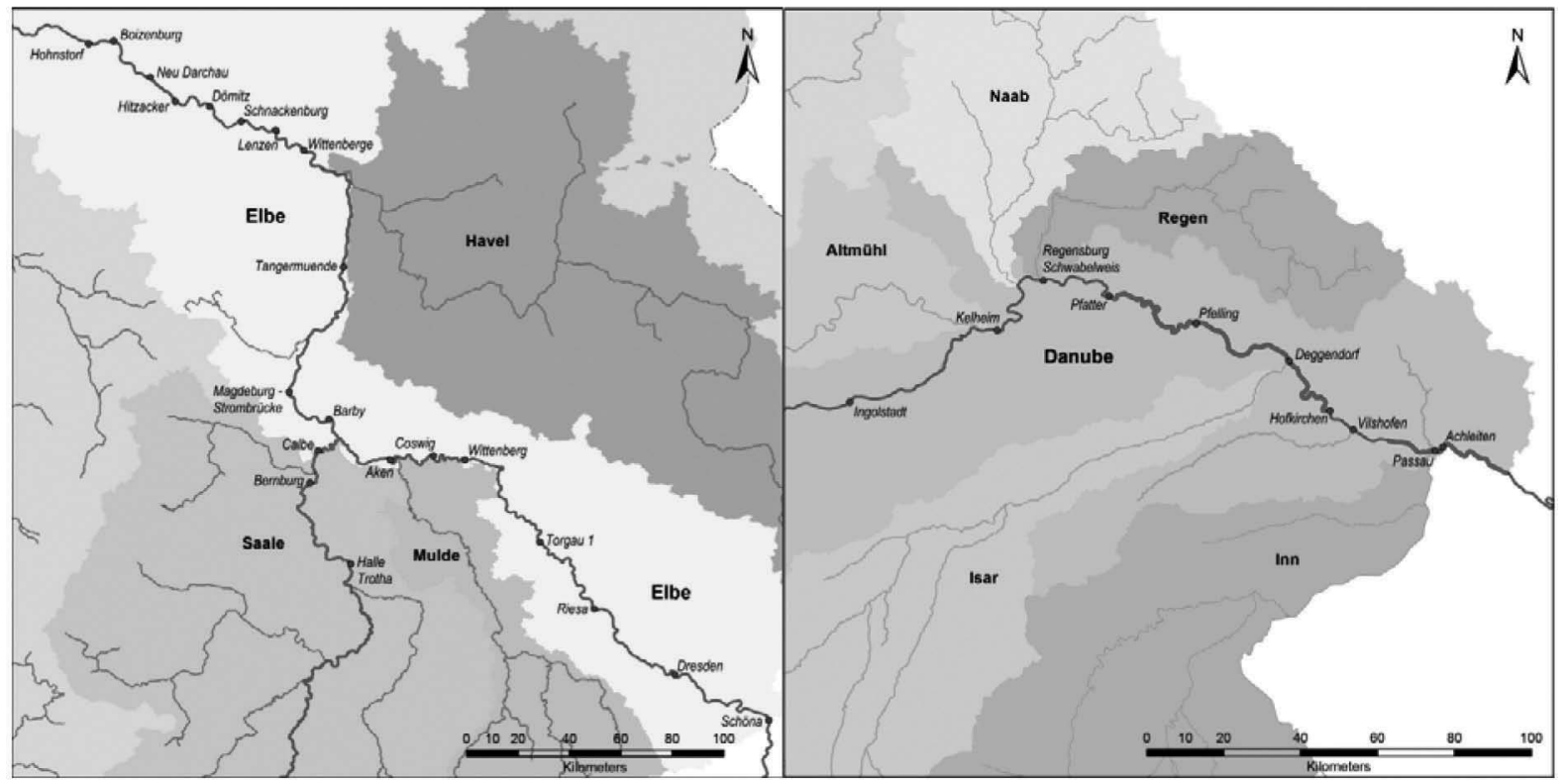

Fig. 2: River stretches with new record water levels (in red) since gauge installation during the June 2013 flood for the Elbe (left) and the Danube (right) (figure redrawn from BfG, 2013; colors indicate different catchments).

tions. In total, from 31 May to 4 June, traffic disruptions on federal roads („Bundesstraße") and highways occurred in 89 German districts („Landkreis“) [CEDIM, 2013b].

\section{COMPARISON TO OTHER LARGE-SCALE FLOODS}

Figure 3 shows the time series of annual maximum flow for the gauges Dresden (Elbe) and Hofkirchen (Danube). These are the gauges with the longest systematic observations in the German parts of the Elbe and Danube catchments. At gauge Dresden the 2002 and 2013 floods rank as the second and third largest floods, respectively, within the observation period of more than 200 years. A flood of similar peak discharge occurred only once and roughly 160 years ago: the flood-of-record in 1845 . In addition to the two extreme floods in 2002 and 2013, there has been a significant flood peak in 2006. Hence, the last decade has seen remarkable flood activity, in particular given the six decades of low flood peaks prior to the 2002 flood. Overall the flood time series of Dresden/Elbe shows high variability. In contrast, the flood behavior at Hofkirchen/Danube is characterized by lower variability. The 2013 flood is the largest flood within the 110 years of observations; floods with similar peak discharge occurred in 2002 and 1954.

To understand the hydrological severity of the June 2013 flood, we compare it with the set of trans-basin floods for Germany for the period 1952-2002 compiled by Uhlemann et al. [2010]. They proposed two measures for comparing trans-basin floods: $\mathrm{L}$ is defined as the percentage of the German river network affected by at least a 2-year flood, and the overall event severity $\mathrm{S}$ is derived as the sum of weighted peak discharges, normalized by the median annual flood, whereas the weights are the ratios of the river stretch length associated with a certain gauge to the total length of the river network. Hence, $\mathrm{S}$ is an index for the overall event severity considering both the heterogeneous spatial extent as well as the locally varying magnitudes of trans-basin floods. In total,
Uhlemann et al. [2010] identified 80 trans-basin floods in the period 1952-2002. Figure 4 shows the ranking of these floods and in addition the June 2013 flood. According to the severity index S, the June 2013 has been more severe than all other floods in Germany between 1952 and 2002. Although the floods in the period 2003-2012 are not included in Figure 4 due to lack of data, we can conclude that the 2013 flood also surpassed all floods since 1952.

Table 1 compares the June 2013 with the other disastrous, most recent summer floods in Germany and with the exceptional summer flood in 1954. A particular feature of the June 2013 flood was the contribution of the initial state of the catchments with very wet or saturated soils. Although the event rainfall was intense and widespread, the totals were smaller compared to the 2002 flood. However, the combination of heavy rainfall with the extremely wet initial conditions led to the extraordinary hydrological severity. The severity index according to Uhlemann et al. [2010] is at least 133 for June 2013, which is almost twice the value of the August 2002 flood (severity index 71) and also much larger than that for the summer 1954 flood (severity index 82).

It is particularly interesting to compare the impacts of the two floods in 2002 and 2013. The current, preliminary damage assessments estimate at most the same economic loss for both floods, although the June 2013 flood was much more severe in hydrological terms. Although there are no detailed studies available yet, the comparable (or even reduced) loss may be the outcome of significant improvements in flood risk management during the last ten years. The 2002 flood has triggered comprehensive risk reduction measurements, such as - massive investments in structural flood defense, e.g., Saxony alone invested more than 500 million $€$ since 2002 in structural defense measures [Bröker, 2013],

- the 5-point-programme of the German federal government to improve precautionary flood protection measures [BMU, 2003],

- changes in the Federal Building Code of Germany which now requires communities to note statutory flood-plain 

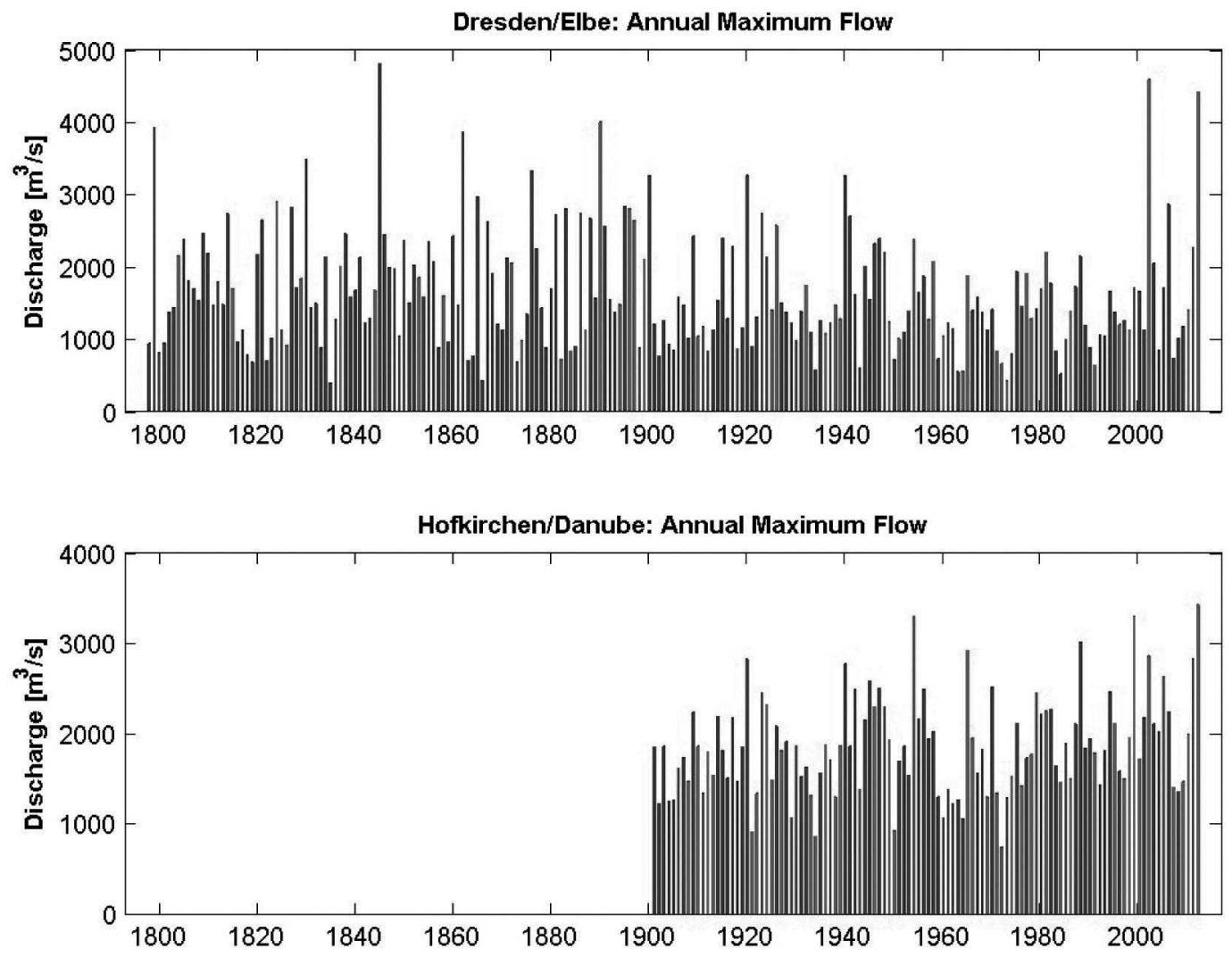

Fig. 3: Annual maximum discharge for Dresden, Elbe river, and Hofkirchen, Danube river. The location of the gauges is indicated in Fig. 2. Blue: annual maximum discharge in winter (Nov-Apr); Red: annual maximum discharge in summer (May-Oct).

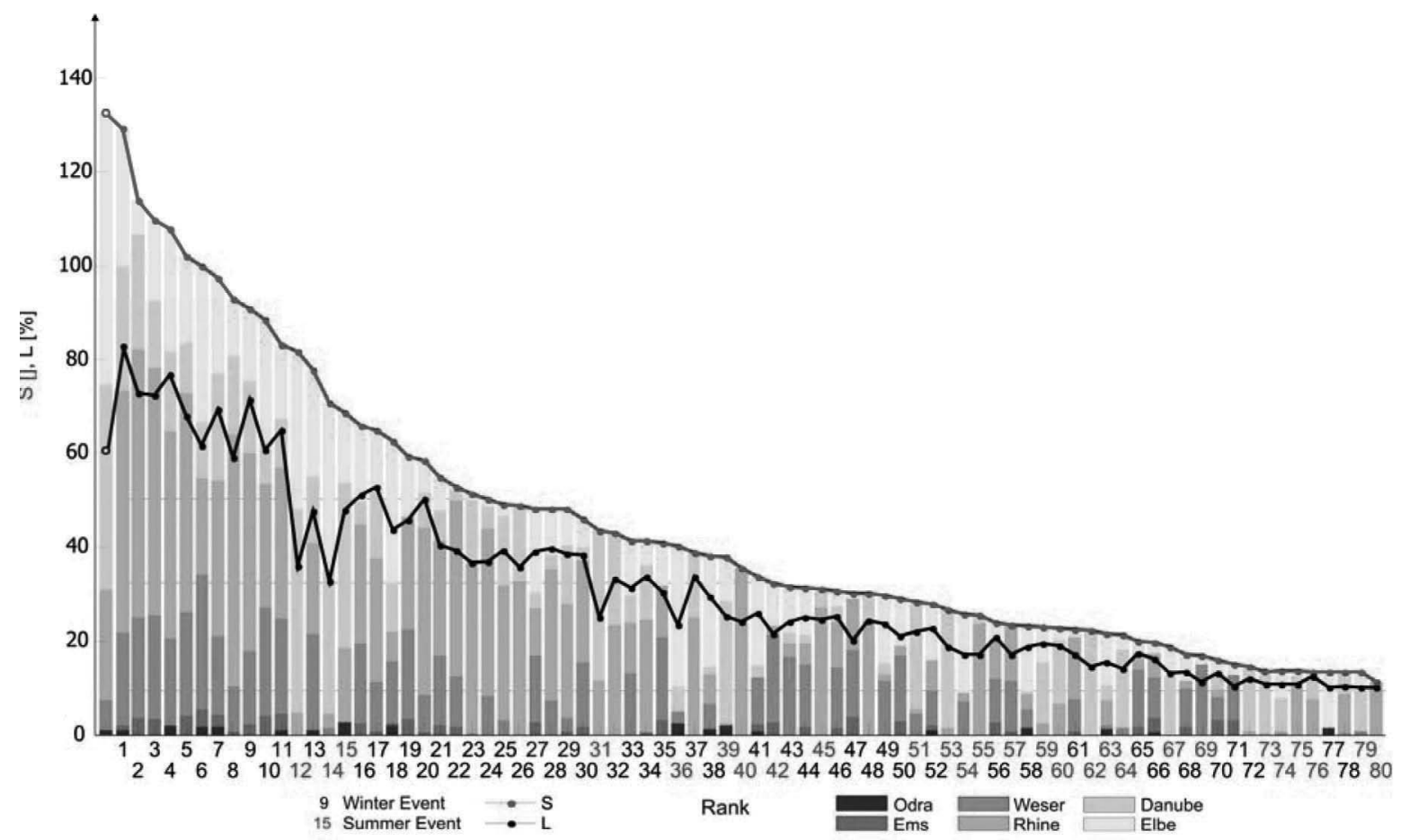

Fig. 4: Comparison of the flood 2013 with the set of trans-basin floods for Germany for 1952-2002 compiled by Uhlemann et al. [2010]. Large-scale floods are ranked according to the severity index $S$ from left to right. The June 2013 flood (open circle) ranks as the most severe flood. Due to missing data from June 2013, the severity of the 2013 flood is based on a subsample of the gauge set of Uhlemann et al. (2010). Gauges without data are included as 'not affected'. Hence, the severity of the 2013 flood is a lower bound estimate and would increase if all data would be available. 
Table 1: Comparison of large floods in the Danube and Elbe catchment [based on CEDIM, 2013b]. Severity S: peak flow exceeding the and normalized by the 2-year peak flow and multiplied by associated river length; L: fraction of river length with peak flow > 2-year flood [Uhlemann et al., 2010].

\begin{tabular}{|c|c|c|c|c|}
\hline Flood & Cause & $\begin{array}{l}\text { River/gauge (federal state) } \\
\text { with highest return period }\end{array}$ & $\begin{array}{c}\text { Severity } \\
\text { S: } \text { severity index } \\
\text { L: spatial extent }\end{array}$ & $\begin{array}{l}\text { Economic loss for Germany } \\
\text { (not corrected for inflation) }\end{array}$ \\
\hline July 1954 & Heavy rain & $\begin{array}{l}>200 \\
\text { Weiße Elster/Greiz } \\
\text { (Thuringia) }\end{array}$ & $\begin{array}{l}S=81.7 \\
L=36.1 \%\end{array}$ & No information \\
\hline May 1999 & Heavy rain & $\begin{array}{l}\sim 200 \\
\text { Ammer/Stege } \\
\text { (Baden-Wuerttemberg) }\end{array}$ & $\begin{array}{l}\mathrm{S}=43.6 \\
\mathrm{~L}=25.0 \%\end{array}$ & 412 million $€[$ Kron, 2004] \\
\hline August 2002 & Heavy rain & $\begin{array}{l}>500 \\
\text { Freiberger Mulde/Nossen } \\
\text { (Saxony) }\end{array}$ & $\begin{array}{l}\mathrm{S}=70.9 \\
\mathrm{~L}=32.8 \%\end{array}$ & 11,8 billion $€$ [Kron, 2004] \\
\hline August 2005 & Heavy rain & $\begin{array}{l}<75 \\
\text { Lech/Landsberg } \\
\text { (Baden-Wuerttemberg) }\end{array}$ & No information & 190 million $€[$ LfU, 2006] \\
\hline June 2013 & $\begin{array}{l}\text { Heavy rain } \\
\text { on wet soils }\end{array}$ & $\begin{array}{l}\text { 500 } \\
\text { Zwickauer Mulde/ } \\
\text { Wechsel-burg } \\
\text { (Saxony) }\end{array}$ & $\begin{array}{l}\mathrm{S}>=132.5 \\
\mathrm{~L}=60.7 \% \\
\text { (preliminary calcu- } \\
\text { lations) }\end{array}$ & $\begin{array}{l}\sim 12 \text { billion } € \text { (Fitch Rating, } \\
\text { first estimate from } 11 \text { June } 2013 \text { ); } \\
\sim 6.7 \text { billion } € \text { (Bundesregierung, } \\
\text { estimate from } 19 \text { September } 2013 \text { ) + } \\
\text { insured losses of } \sim 2 \text { billion } € \\
(\mathrm{GdV}, \text { estimate from } 2 \text { July } 2013)\end{array}$ \\
\hline
\end{tabular}

zones and flood-prone zones in their development plans [Petrow et al., 2006],

- significant investments of private households in precautionary measures. A telling example is leaking heating oil. In 2002, many buildings had increased damage due to heating oil leaking from tanks in the flooded basements. In 2013, only occasional cases of leaking heating oil has been reported [KW, 2013].

\section{CONCLUSIONS}

The June 2013 flood was, in hydrological terms, the most severe flood in Germany, at least for the last 6 decades for which a hydrological flood severity has been calculated. The enormous hydrological severity was caused by widespread and intense rainfall on very wet soils due to exceptionally high rainfall in the month preceding the event. Although the hydrological severity of the flood 2013 is at least twice as high as the severity of the flood 2002, the damages in 2013 are expected to be significantly lower than in 2002 - in particular taking into account the inflation effect which would raise the damages of 2002 to approximately 15 billion $€$ [CEDIM, 2013b]. Generally, it is assumed that the improvements in flood risk management since 2002 have prevented higher damage. However, detailed investigations are necessary to support this assumption.

\section{ACKNOWLEDGEMENTS}

We gratefully acknowledge the provision of data by (a) Bavarian State Office of Environment, (b) Saxony State Office of Environment, Agriculture and Geology, (c) Sachsen-Anhalt Office of Flood Protection and Water Management, (d) Thüringen State Office of Environment and Geology (TLUG), (e) Flooding Forecast Centre Baden Württemberg, (f) Water and Shipping Management of the Fed. Rep. (WSV), prepared by the Federal Institute for Hydrology (BfG).

\section{REFERENCES}

Bfg (Bundesanstalt Für Gewässerkunde) (2013) Länderübergreifende Analyse des Juni-Hochwassers 2013. BfG-Bericht. 1797 : 69 p

Bmu (Bundesministerium Für UmWelt, Naturschutz Und Reaktorsicherheit - German Federal Ministry For The Environment, Nature Conservation And Nuclear SAFETY) (2003) - 5-Punkte-Programm der Bundesregierung: Arbeitsschritte zur Verbesserung des vorbeugenden Hochwasserschutzes. Federal Ministry for the Environment. Nature Conservation and Nuclear Safety (Publ.), Bonn

BRÖKER S. (2013) - Hochwasservorsorge muss vier Säulen umfassen - UFZ zieht Resümee aus aktuellem Hochwasser. $K W$ Korrespondenz Wasserwirtschaft. 6(7) : 360

BundesRegierung (2013) — Bericht zur Flutkatastrophe 2013 Katastrophenhilfe, Entschädigung, Wiederaufbau. Deutscher Bundestag. Drucksache 17/14743, available at: http://dip 21.bundestag.de/dip21/btd/17/147/1714743.pdf, published 19.9.2013 (accessed 12 Nov. 2013)

Cedim (2013) - Juni-Hochwasser 2013 in Mitteleuropa - Fokus Deutschland. Bericht 1: Vorbedingungen, Meteorologie, Hydrologie. www.cedim.de (accessed 31 Oct. 2013)

Cedim (2013) - Juni-Hochwasser 2013 in Mitteleuropa - Fokus Deutschland. Bericht 2: Auswirkungen und Bewältigung. www. cedim.de (accessed 31 Oct. 2013)

Conradt T., Roers M., Schröter K., Elmer F., Hoffmann P., Kосн H. (2013) - Vergleich der Extremhochwässer 2002 und 2013 im deutschen Teil des Elbegebiets und deren 
Abflusssimulation durch SWIM-live. Hydrologie und Wasserbewirtschaftung. 57(5) 241-245

EM-Dat (The International Disaster Data Base, Cred); Http://Www. Emdat.Be/Database (Accessed June 2012)

Fitch Ratings (2013) - German Flood Claims May Hit EUR3bn, available at: http://www.fitchratings.com/gws/en/fitchwire/ fitchwirearticle/German-Flood-Claims?pr id $=793326 \& \mathrm{~cm}$ sp=homepage-__FitchWire-_o20German\%20Flood\% 20 Claims\%20May\%20Hit\%20EUR3bn;\%20Credit\%20 Impact\%20Limited, published 11.6.2013 (accessed 12 Nov. 2013)

GDV (2013) — Erste Schadenbilanz: Hochwasser 2013 verursacht 180.000 versicherte Schäden in Höhe von fast 2 Milliarden Euro. Pressemitteilung des Versicherungswirtschaft 2.7.2013, available at: http://www.gdv.de/2013/07/ hochwasser-2013-verursacht-180-000-versicherte-schaeden-in-hoehe-von-fast-2-milliarden-euro/laccessed 12 Nov. 2013)
Kron W. (2004) - Zunehmende Überschwemmungsschäden: Eine Gefahr für die Versicherungswirtschaft? $A T V-D V W K$ Bundestagung, Würzburg

Kw (2003) - Sachsen: Hochwasserschäden bei rund zwei Milliarden Euro. KW Korrespondenz Wasserwirtschaft. 6(8) : 409

Lfu (Landesanstalt Für Umweltschutz) (2006) August-Hochwasser 2005 in Südbayern, Augsburg

Petrow T., Thieken A.H., Kreibich H., Merz B., Bahlburg C.H. (2006) - Improvements on flood alleviation in Germany: Lessons learned from the Elbe flood in August 2002. DOI 10.1007/s00267-005-6291-4. Environmental Management. 38(5) $717-732$

Uhlemann S., Thieken A. H., And Merz B. (2010) — A consistent set of trans-basin floods in Germany between 1952 - 2002. doi 10.5194/hess-14-1277-2010. Hydrol. Earth Syst. Sci. 14 : $1277-1295$ 